\title{
Inflammatory Ideas about Sleep Apnea
}

\author{
Neil S. Cherniack \\ Department of Medicine, New Jersey Medical School, Newark, N.J., USA
}

In this issue of Respiration, Imagawa et al. [1] continue their studies of the augmented levels of vascular endothelial growth factor (VEGF) in 110 sleep apnea patients, reporting that they are not explained by increases in the proinflammatory cytokines tumor necrosis factor (TNF)alpha or interleukin (IL)-6.

In a previous study, the same authors found in the same group of patients that erythropoietin (EPO) levels were slightly increased and VEGF levels were increased by a greater amount [2]. The patients studied had an apnea-hypopnea index (AHI) that ranged between 30 and more than 110, although only 10 patients had AHIs of 90 or more. It is of interest that EPO levels were significantly elevated in all patients with AHI levels less than 90 but not in the more severely affected group, perhaps because of the small numbers involved. VEGF levels were significantly elevated even in the small group with the greatest AHI.

Intermittent hypoxia as occurs in sleep apnea has multiple physiological consequences, including increases in EPO and VEGF. Hypoxia has been shown to decrease the breakdown of a transcription factor, hypoxia-inducible factor-1, which triggers the induction of many genes like EPO and VEGF and which compensates for the reduction in blood oxygen levels by increasing red cell mass (EPO) or inducing the formation of new blood vessels (VEGF) [3]. It also induces genes responsible for endothelin and multiple enzymes involved in anaerobic metabolism [4].
Some cytokines, such as IL-8, IL-6, and IL-1, have been reported to increase VEGF levels, but in any case even if elevated cytokine levels were found, the methods used in this paper [1] would not have demonstrated a causal relationship but only an association. What is somewhat surprising is that no elevation in either TNF-alpha or IL-6 was found. However, only a single measurement of the cytokines was made in each patient in the morning upon awakening, and both IL-6 and TNF-alpha have circadian rhythms [5, 6].

The transcription factor NF-kappaB can also be induced by hypoxia, and it can increase production of both TNF-alpha and IL-6 [3]. TNF-alpha also acts in a positive feedback manner to increase NF-kappaB. In addition, TNF-alpha and IL-6 levels have been reported by others to be increased in patients with obstructive sleep apnea, although a complicating issue is that increasing body mass index correlates positively with both cytokine levels and AHI.

There is increasing evidence indicating that cytokine levels can significantly affect sleep both positively and negatively. The cytokines IL-1, IL-6 and TNF-alpha, in particular, promote sleep when injected into animals $[7,8]$.

In addition, obstructive sleep apnea is sometimes associated with airway inflammation [9]. TNF-alpha and IL-6 are critical elements in inflammatory responses. Imagawa et al. [1] point out that inflammation also increases

\begin{tabular}{ll}
\hline KARGER & ( ) 2004 S. Karger AG, Basel \\
0025-7931/04/0711-0020\$21.00/0 \\
$\begin{array}{l}\text { Fax +4161306 1234 } \\
\begin{array}{l}\text { E-Mail karger@karger.ch } \\
\text { www.karger.com }\end{array}\end{array}$ & $\begin{array}{l}\text { Accessible online at: } \\
\text { www.karger.com/res }\end{array}$
\end{tabular}

Neil S. Cherniack

Office of the Dean, Department of Medicine, UMDNJ - New Jersey Medical School 185 South Orange Avenue

Newark, NJ 07103-2714 (USA)

Tel. +1 973972 7937, Fax +1973972 7104, E-Mail cherniac@umdnj.edu 
VEGF. Experimentally produced resistive breathing, which occurs spontaneously in obstructive sleep apnea, is reported to increase both IL-6 and TNF-alpha [10, 11].

It is easy to understand how sleep apnea, by producing intermittent systemic hypoxia, increases VEGF. Even local hypoxia gives rise to increases in VEGF. VEGF is the major mediator of angiogenesis. Angiogenesis is an important factor in many diseases, including cancer, and it promotes tumor spread, retinopathies and rheumatoid arthritis. It would be interesting to see whether the incidence of these diseases is greater in patients with obstructive sleep apnea.

\section{References}

1 Imagawa S, Yamaguchi Y, Ogawa K, Obara N Suzuki N, Yamamoto M, Nagasawa T: Interleukin- 6 and tumor necrosis factor- $\alpha$ in patients with obstructive sleep apnea-hypopnea syndrome. Respiration 2004;71:24-29.

2 Imagawa S, Yamaguchi Y, Higuchi M, Neichi T, Hasegawa Y, Mukai HY, Suzuki N, Yamamoto M, Nagasawa T: Levels of vascular endothelial growth factor are elevated in patients with obstructive sleep apnea-hypopnea syndrome. Blood 2001;98:1255-1257.

3 Semenza GL: Hypoxia-inducible factor 1: Oxygen homeostasis and disease pathophysiology. Trends Mol Med 2001;7:345-350.

4 Semenza GL: Hypoxia-inducible factor 1: Control of oxygen homeostasis in health and disease. Pediatr Res 2001;49:614-617.
5 Vgontzas AN, Papanicolaou DA, Bixler EO, Lotsikas A, Zachman K, Kales A, Prolo P, Wong ML, Licinio J, Gold PW, Hermida RC, Mastorakos G, Chrousos GP: Circadian interleukin-6 secretion and quantity and depth of sleep. J Clin Endocrinol Metab 1999;84:26032607.

6 Vgontzas AN, Zoumakis M, Papanicolaou DA, Bixler EO, Prolo P, Lin HM, Vela-Bueno A, Kales A, Chrousos GP: Chronic insomnia is associated with a shift of interleukin- 6 and tumor necrosis factor secretion from nighttime to daytime. Metabolism 2002;51:887-892.

7 Krueger JM, Majde JA: Humoral links between sleep and the immune system: Research issues. Ann NY Acad Sci 2003;992:9-20.
8 Krueger JM, Obal FJ, Fang J, Kubota T, Taishi $\mathrm{P}$ : The role of cytokines in physiological sleep regulation. Ann NY Acad Sci 2001;933:211221.

9 Rubinstein I: Upper airway inflammation in obstructive sleep apnea. Am J Respir Crit Care Med 2002;165:1023-1024.

10 Vassilakopoulos T, Katsaounou P, Karatza MH, Kollintza A, Zakynthinos S, Roussos C: Strenuous resistive breathing induces plasma cytokines: Role of antioxidants and monocytes. Am J Respir Crit Care Med 2002;166:15721578.

11 Vassilakopoulos T, Zakynthinos S, Roussos C: Strenuous resistive breathing induces proinflammatory cytokines and stimulates the HPA axis in humans. Am J Physiol 1999;277: R1013-R1019. 